\title{
Factors Affecting Ginger Production in Surkhet District, Nepal
}

\author{
Sudip Mahat ${ }^{1}$, Sundar Sapkota $^{2}$, Sanjib Sapkota $^{2 *}$, Krishna Katuwal $^{3}$ \\ ${ }^{1}$ Department of Agriculture, Agriculture and Forestry University, Rampur, Nepal. \\ ${ }^{2}$ Department of Biology, Eastern New Mexico University, Portales, NM 88130, USA. \\ ${ }^{3}$ Department of Crop and Soil Sciences, University of Georgia, Athens, GA 30602, USA
}

\begin{abstract}
Ginger is a high value crop belongs to family Zingiberaceae. Ginger has multiple health benefits and can be easily grown in mid-hill regions of Nepal. The major challenge is the limited availability of information on factors affecting ginger yield. The objective of this project was to analyze different factors influencing ginger production. The study was conducted in Surkhet district of Nepal in 2018. A total of 100 farmers (60 and 40 from Barahtal and Chingad rural municipalities respectively) were selected using simple random sampling technique. Primary data were collected using interview schedule, focus group discussion and key informant interview. Data were analyzed using Statistical Package for the Social Sciences (SPSS) and Microsoft Excel. The descriptive statistics, chi-square test and correlation were used to derive conclusion. The average age and land under ginger cultivation were 41 years and 0.093 hectare respectively. Average ginger production in the study area was $980 \mathrm{~kg}$ per ropani. There was a strong positive relationship between farm size and ginger production. Training, subsidy and labor crisis had positive association with ginger production. However, family size and years of schooling were not significant but positively correlated. It is recommended that concerned authorities should give emphasis on farmer training, extension services, and subsidy to enhance ginger production.
\end{abstract}

Keywords: Ginger; Production; Farmers

\section{Introduction}

Ginger (Zingiber officinale Roscoe) is an important high value crop belonging to family Zingiberaceae (Singletary, 2010). It is commonly utilized as a spice, pickles, candies, and medicinal herb (White, 2007; FAO, 2017). Ginger is rich in different phenolic compounds such as gingerols, gingerones, paradols, and shogaols (Karna et al., 2011). Ginger has multiple health benefits such as anticancer, antioxidant, anti-proliferative, anti-inflammatory, and antidiabetics (White, 2007). In addition, ginger is used to treat cardiovascular problems, asthma, arthritis, and menstrual irregularity (Singletary, 2010; Karna et al., 2011). Ginger performed best in a temperature range of 19 to $28^{\circ} \mathrm{C}$. The suitable $\mathrm{pH}$ and relative humidity for ginger production are 6.0-6.5 and 70-90 \%, respectively. Nature has glorified Nepal with an ideal climate for growing ginger scattered from east to west of mid-hill regions of the country up to 1600 meter above sea level. Nepalese farmers traditionally cultivate two landraces of ginger: Nase and Bose. Ginger Research Program (GRP), Salyan has launched two varieties of ginger: Kapurkot Aduwa-1 in 2001 and Kapurkot Aduwa-2 in 2016 (AICC, 2018). Ginger is widely grown in mid hills of Nepal which has a large production and export potential (ITC, 2007). Nepal ranks the fourth position in terms of global ginger production with $11.5 \%$ of

\section{Cite this article as:}

S. Mahat et al. (2019) Int. J. Appl. Sci. Biotechnol. Vol 7(2): 269-273. DOI: 10.3126/ijasbt.v7i2.24650

\section{*Corresponding author}

Sanjib Sapkota,

Department of Biology, Eastern New Mexico University, Portales, NM 88130, USA

Email: sanjib.sapkota@enmu.edu

Peer reviewed under authority of IJASBT

(C) 2019 International Journal of Applied Sciences and Biotechnology 
the world's production after India, China and Indonesia (FAO, 2017). Global output of Nepalese ginger production is around 2.02 million tons (Nepal Dispatch, 2018). India is the main export market for Nepalese ginger (ABPSD, 2014).

Surkhet (latitude $28^{\circ} 35^{\prime} 59.99^{\prime \prime}$ N, longitude $81^{\circ} 37^{\prime} 59.99^{\prime \prime}$ E) is one of the major ginger producing districts of Nepal. The total area of ginger production in Surkhet was 510 thousand hectares with a total production of 8,094 metric tons (DADO, 2017). Farmers obtained yield of about 15.80 MT/ha which is lower compared to potential yield of about 21.40 MT/ha (GRP, 2009). Despite the favorable climatic conditions, productivity is stagnant since fiscal year 2013. The social factors influencing crop production are farmer age, gender, level of education, farm size, access to extension services, farmers organization and markets (Mannaf and Uddin, 2012). These factors and their degrees of influences depend on the type of crop and production technologies (Altarawneh et al., 2012). The objective of this research was to analyze the relationship between various socio-economic factors such as gender, age, education, total land holding, farmer access to extension services, participation in training, subsidy received, and labor availability with ginger production.

\section{Materials and Methods}

We selected Surkhet district of Nepal for study as there was higher production potential of ginger. In Surkhet, we selected Barahtal and Chingad rural municipalities for our study as they were the residence of commercial ginger growers.

\section{Selection of Ginger Farmers}

Our sample population size was 500 ginger growers in Barahtal and Chingad rural municipalities of Surkhet district. The list of ginger growers was obtained from Ginger Implementation Zone Surkhet, Surkhet. Sixty and forty ginger growers (in total 100) were randomly selected from Barahtal and Chingad rural municipalities respectively.

\section{Data Collection and Analysis}

The information was collected through household survey using interview schedule, focus group discussion and key informant interview.

The data obtained were analyzed using SPSS 25 (SPSS, 2009) and Microsoft Excel. The descriptive statistics such as means, frequency, percentage, and standard deviation were used to derive conclusion. Chi-square test $\left(\chi^{2}\right)$ was used to measure the association of independent categorical variables such as gender of respondents, membership of farmers' group, subsidy received, and training received with dependent variable that is level of ginger production. Based on average ginger production, production levels were categorized as low and high, and relationships of individual production level to different socioeconomic factors were analyzed using Chi-square test. Chi-square test $\left(\chi^{2}\right)$ shows the association between two categorical variables and is widely used method to judge the significance of association between attributes (Peck et al., 2015). Correlation tool was used to show the relationship between two continuous variables.

\section{Results and Discussion}

\section{Socio-Economic Characteristics of the Farmers}

The socio-economic variables such as gender, age, education, ethnicity, family size, total land holding, and farm size were examined. The studied institutional variables were access to extension services, training and subsidy. Sixty-four percent of the household heads were male while $36 \%$ were female indicating that most households are male headed as shown in Table 1 . The findings revealed that 24 $\%$ of the household heads had no formal education, $29 \%$ had primary level of education, $37 \%$ had secondary level of education, $1 \%$ had higher secondary education and only $9 \%$ had pre-primary level of education as shown in Table 1. Generally, greater the education level greater would be the efficiency of producers (Battese and Coelli, 1995). Low literacy levels can therefore hamper overall agricultural production including ginger production. The average age of the farmers was 41 as shown in Table 2. This suggests that farmers engaged in ginger production were older people than younger ones. Similar to our result in Nepal, Ezra et al. (2017) also found that farmers below 50 years are actively engaged in ginger production in Nigeria. Both findings from Nepal and Nigeria indicated less interest in ginger production among young generation (less than 30). Developing a creative training program that could improve interest of younger people in ginger production would bring improvement and sustainability in ginger production by using youthful energy.

The average farm size was 0.093 ha which indicates that farmers in Barahtal and Chingad rural municipalities of Surkhet district had small farm holdings (Table 2). The percentage of farmers who attended training was $31 \%$ as shown in Table 1 which indicates that farmers benefitted from field-based training were less. Therefore, extension services should be disseminated among farmers to improve production practices thereby help to enhance farm production (Mmasa and Mhagama, 2017). Only $24 \%$ of respondents have visited agriculture service center monthly to seek advice (Table 1). The probable reasons may be either farmers are reluctant to visit the agriculture service center, or farmers are unaware of the agricultural service center. Fifty-two of the farmers received subsidy from supporting organizations to cultivate ginger while $48 \%$ of farmers had no access as shown in Table 1. This indicate that mobility of supporting organizations and governmental bodies were less in the study area. 
Table 1: Socio-economic characteristics of the ginger growers $(\mathrm{N}=100)$.

\begin{tabular}{|c|c|c|}
\hline Parameters & Frequency & Percent \\
\hline \multicolumn{3}{|l|}{ Gender } \\
\hline Male & 64 & 64 \\
\hline Female & 36 & 36 \\
\hline \multicolumn{3}{|l|}{ Age (years) } \\
\hline Less than 30 & 13 & 13 \\
\hline 30 to 53 & 76 & 76 \\
\hline Above 53 & 11 & 11 \\
\hline \multicolumn{3}{|l|}{ Education } \\
\hline Illiterate & 24 & 24 \\
\hline Pre-primary & 9 & 9 \\
\hline Primary (up to 5) & 29 & 29 \\
\hline Secondary (up to 10) & 37 & 37 \\
\hline Higher secondary and further (above 10) & 1 & 1 \\
\hline \multicolumn{3}{|l|}{ Ethnicity } \\
\hline Brahmin/Chhetri & 76 & 76 \\
\hline Janajati & 17 & 17 \\
\hline Dalit & 7 & 7 \\
\hline \multicolumn{3}{|l|}{ Family size (number) } \\
\hline Small (up to 4) & 25 & 25 \\
\hline Medium (5 to 10$)$ & 65 & 65 \\
\hline Large (greater than 10) & 10 & 10 \\
\hline \multicolumn{3}{|l|}{ Total land holding (ha) } \\
\hline Small (less than 0.26) & 25 & 25 \\
\hline Medium (0.27 to 0.72$)$ & 63 & 63 \\
\hline Large (greater than 0.72 ) & 12 & 12 \\
\hline \multicolumn{3}{|l|}{ Farmer access to extension services } \\
\hline Once a month & 24 & 24 \\
\hline Once in six months & 34 & 34 \\
\hline Once a year & 20 & 20 \\
\hline Never & 22 & 22 \\
\hline \multicolumn{3}{|l|}{ Participated in training } \\
\hline Yes & 31 & 31 \\
\hline No & 69 & 69 \\
\hline \multicolumn{3}{|l|}{ Membership of farmers' group } \\
\hline Yes & 74 & 74 \\
\hline No & 26 & 26 \\
\hline \multicolumn{3}{|l|}{ Subsidy received } \\
\hline Yes & 52 & 52 \\
\hline No & 48 & 48 \\
\hline
\end{tabular}

Source: Field Survey, 2018.

Table 2: Summary of the characteristics of various variables in the model.

\begin{tabular}{|lll|}
\hline Variable & Mean & Standard deviation \\
\hline Age (years) & 40.79 & 11.85 \\
\hline Family Size (number) & 6.63 & 2.73 \\
\hline Land holding (ha) & 0.49 & 0.23 \\
\hline Farm Size (ha) & 0.093 & \\
\hline
\end{tabular}

Source: Field Survey, 2018. 


\section{Production Level of Ginger}

Average ginger production in the study area was $980 \mathrm{~kg}$ per ropani. Based on this, ginger production was categorized in two production levels; low (ginger yield less than $980 \mathrm{~kg}$ ) and high (ginger yield more than $980 \mathrm{~kg}$ ).

Table 3: Production level of ginger $(\mathrm{N}=100)$.

\begin{tabular}{|lll|}
\hline $\begin{array}{l}\text { Production level of } \\
\text { ginger }\end{array}$ & Frequency & Percent \\
\hline Low & 64 & 64 \\
\hline High & 36 & 36 \\
\hline
\end{tabular}

Source: Field Survey, 2018. Mean $(\mathrm{X})=980 \mathrm{~kg} / \mathrm{ropani}$

\section{Chi-Square Analysis Between Factors and Ginger Production}

Results of Chi-square test on relationship between characteristics of ginger farmer and ginger production level revealed that gender and farmer group membership have no statistically significant relationship with level of ginger production at 0.05 probability level as shown in Table 4 . This implies that farmers group in the study area may unable to help farmers to improve their production. Similar result was observed by Makarau (2013) that there was no association between gender and ginger production in Nigeria. However, labor crisis and training received showed a positive association with ginger yield as shown in Table 4. This result was supported by Erza et al. (2017) who reported that labor availability is positively associated with crop production in Kaduna state of Nigeria. Ginger farming is a labor-intensive enterprise. So, the availability of labor influenced ginger production.

A positive relationship was observed between training received and ginger production as shown in Table 4. Trainings on cultivation practices, pest management strategies, and improved technologies may help farmers to develop skills and knowledge required to increase ginger production. The chi-square analysis implies that subsidy had highly significant influence on ginger production indicating that increasing subsidy will increase ginger production as shown in Table 4. Subsidies act as an incentive for farmers to expand their cultivation area thereby help to improve production.

Table 4: Relationship between different factors and ginger production $(\mathrm{N}=100)$.

\begin{tabular}{|lllllll|}
\hline \multirow{2}{*}{ Factors } & \multicolumn{9}{c}{ Production level } & $\left(\chi^{2}\right.$ Cal $)$ & $\boldsymbol{(}^{2}$ tab) & P value \\
\cline { 2 - 7 } & Low & High & Total & & & \\
\hline Gender & & & & $0.11^{\text {ns }}$ & 3.84 & 0.67 \\
\hline Fale & $43(43)$ & $21(21)$ & $64(64)$ & & & \\
\hline Training received & $23(23)$ & $13(13)$ & $36(36)$ & & & \\
\hline Yes & & & & $4.14^{*}$ & 3.84 & 0.029 \\
\hline No & $16(16)$ & $15(15)$ & $31(31)$ & & & \\
\hline Subsidy received & $50(50)$ & $19(19)$ & $69(69)$ & & & \\
\hline Yes & & & & $7.131^{* *}$ & 3.84 & 0.003 \\
\hline No & $28(28)$ & $24(24)$ & $52(52)$ & & & \\
\hline Membership of farmer group & $38(38)$ & $10(10)$ & $48(48)$ & & & \\
\hline Yes & $45(45)$ & $29(29)$ & $74(74)$ & & & \\
\hline No & $21(21)$ & $5(5)$ & $26(26)$ & & & \\
\hline Labor crisis & & & & & \\
\hline Yes & $42(42)$ & $14(14)$ & $56(56)$ & & & \\
\hline No & $24(24)$ & $20(20)$ & $44(44)$ & & & \\
\hline
\end{tabular}

Source: Field Survey, 2018, Note: ns= non-significant at $5 \%$ probability level, ${ }^{*}=$ significant at $5 \%$ probability level, $* *=$ significant at $1 \%$ probability level

Table 5: Correlation analysis between factors and production

\begin{tabular}{|llll|}
\hline Factors & $\begin{array}{l}\text { Pearson Correlation } \\
\text { ' } \mathbf{r}\end{array}$ & $\begin{array}{l}\text { Sig. (2 tailed) } \\
\text { 'p' }\end{array}$ & $\begin{array}{l}\text { Sample size } \\
\text { 'N' }\end{array}$ \\
\hline Years of schooling & $0.123^{\mathrm{ns}}$ & 0.223 & 100 \\
\hline Family size (number) & $0.106^{\mathrm{ns}}$ & 0.295 & 100 \\
\hline Land size under ginger production (Ropani) & $0.754^{* *}$ & 0.000 & 100 \\
\hline Age (years) & $-0.072^{\mathrm{ns}}$ & 0.476 & 100 \\
\hline
\end{tabular}

Source: Field Survey, 2018, Note: ns= non-significant at $5 \%$ probability level, **=significant at $1 \%$ probability level, 1 ha= 20 Ropani 
Out of nine socioeconomic factors, five factors were evaluated using correlation. Among them, land size under ginger production showed a strong relationship with ginger production at 0.01 level of significance as shown in Table 5. Makarau (2013) also observed that farm size is positively correlated with ginger yield. Years of schooling, family size and farming experience showed a positive but not significant relationship with ginger production at 0.01 level of significance. Similar result was observed by Makarau et al. 2013 and Ezra et al. 2017. Age of the respondents showed a negative correlation with ginger production indicating that efficiency of time and effort reduced with aging.

\section{Conclusion and Recommendation}

Provision of subsidies, land under ginger cultivation, training received, and labor availability are the major socioeconomic factors affecting ginger production in Surkhet district of Nepal. Following recommendations are suggested to increase ginger production and improve income and livelihood of farmers in the near future.

- Subsidy should be provided to the ginger farmers.

- Trainings and extension services on ginger cultivation should be increased.

- Policies to attract youth toward ginger farming should be formulated and implemented.

- Farmers should be encouraged to extend the area of ginger production.

- Improvement of marketing channel for the benefit of farmers.

\section{Acknowledgments}

Authors would like to thank assistant professor Ramhari Timilsina and Prime Minister Agriculture Modernization Project-Ginger zone Surkhet, Nepal for their financial support and help during the research period.

\section{References}

ABPSD (2014) Statistical Information on Nepalese Agriculture. Ministry of Agriculture Development, Agri-Business Promotion and Statistics Division, Kathmandu, Nepal.

AICC (2018) Krishi Diary 2075. Government of Nepal. Lalitpur: Agriculture Information and Communication Centre.

Altarawneh M, Altahat E and Al-Sharafat A (2012) Evaluation of vegetables farmers participation in agricultural extension activities. American Journal of Agricultural and Biological Sciences 7(2): 201-206. DOI: 10.3844/ajabssp.2012.201.206

Battese GE and Coelli TJ 1995. A model for technical inefficiency effects in a stochastic frontier production function for panel data. Empirical Economics. 20(2): 325-332. DOI: 10.1007/BF01205442
DADO (2017) Annual District Profile. District Agriculture Development Office, Agriculture. Surkhet: DADO.

Ezra D, Akinola MO, Banta AL, Makarau SB and Hussaini A (2017) Socio-economic assessment of ginger production in Jaba local government area of Kaduna state, Nigeria. Asian Journal of Agricultural Extension, Economics and Sociology 15(2) 1-11. DOI: $\underline{10.9734 / A J A E E S / 2017 / 28949}$

FAO (2017) FAOSTAT. Food and Agriculture Organization of United Nations. http://www.fao.org/faostat/en/\#rankings/countries_by_co mmodity

GRP (2009) Technical Annual Report-2008/2009. Kapurkot, Salyan, Nepal: Ginger Research Programme, NARC. http://www.nepaldispatch.com/2013/01/fao-ranks-nepalas-the-worlds-third-largest-ginger-producer/

ITC (2007) Export potential assessment in Nepal: Implemented by the International Trade Center (ITC). Kathmandu: Market analysis section in collabouration with the Trade and Export Promotion Center (TEPC) of Nepal.

Karna P, Chagani S, Gundala SR, Rida PC, Asif G, Sharma V, Gupta MV and Aneja R (2012) Benefits of whole ginger extract in prostate cancer. British Journal of Nutrition 107(4): $\quad 473-484 . \quad$ DOI: $\underline{10.1017 / \mathrm{S} 0007114511003308}$

Makarau SB, Damina A, Daneji MI and Garba AO (2013) Socioeconomic factors influencing the adoption of ginger (Zingiber officinale) farming technologies in Samaru zone of the Kaduna state agricultural development project (Kadp). International Journal of Humanities and Social Science Invention 2(7): 39-44.

Mannaf M and Uddin MT (2012) Socioeconomic factors influencing food security status of maize growing households in selected areas of Bogra district. Bangladesh Journal of Agricultural Economics 35: 177-187.

Mmasa JJ and Mhagama JK (2017) Social-economic factors influencing ginger (Zingiber officinale) productivity among smallholders growers in Tanzania-Case of same district. Journal of Economics and Sustainable Development 8: 12-27.

Nepal Dispatch (2018) Nepal Dispatch. Retrieved 8 27, 2018, from News for all Nepal.

Peck R, Olsen C and Devore JL (2015) Introduction to Statistics and Data Analysis. $5^{\text {th }}$ edition, Cenage Learning, Inc. Ohio, United States.

Singletary K (2010) Ginger: an overview of health benefits. Nutrition Today 45(4): 171-183. DOI: 10.1097/NT.0b013e3181ed3543

SPSS Inc. Released (2009) PASW Statistics for Windows, Version 18.0. Chicago: SPSS Inc.

White B (2007) Ginger: an overview. Am Fam Physician 75(11): 1689-1691. 